\title{
MASTER
}

\section{THE FUSION MATERIALS IRRADIATION TEST FACILITY}

\author{
AT HANFORD
}

E. W. Pottmeyer, Jr.

Apri1 15, 1979

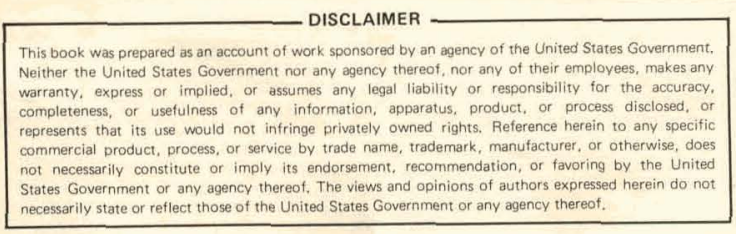

Fusion Reactor Materials Conference

Miami, Florida

January 29-31, 1979

HANFORD ENGINEERING DEVELOPMENT LABORATORY

Operated by Westinghouse Hanford Company, a subsidiary of Westinghouse Electric Corporation, under the Department of Energy Contract No. EY-76-C-14-2170 


\section{DISCLAIMER}

This report was prepared as an account of work sponsored by an agency of the United States Government. Neither the United States Government nor any agency Thereof, nor any of their employees, makes any warranty, express or implied, or assumes any legal liability or responsibility for the accuracy, completeness, or usefulness of any information, apparatus, product, or process disclosed, or represents that its use would not infringe privately owned rights. Reference herein to any specific commercial product, process, or service by trade name, trademark, manufacturer, or otherwise does not necessarily constitute or imply its endorsement, recommendation, or favoring by the United States Government or any agency thereof. The views and opinions of authors expressed herein do not necessarily state or reflect those of the United States Government or any agency thereof. 


\section{DISCLAIMER}

Portions of this document may be illegible in electronic image products. Images are produced from the best available original document. 


\section{MAST}

\section{THE FUSION MATERIALS IRRADIATION TEST FACILITY AT HANFORD*}

E. W. POTTMEYER, $\mathbb{R}$.

Westinghouse Hanford Company, Hanford Engineering Development Laboratory, Rich land, WA 99352, USA

The Fusion Materials. Irradiation Test Facility (FMIT). is a high-energy, high-flux neutron source for fusion materials development. The FMIT linear accelerator will produce a $35 \mathrm{MeV}$ beam of deuterons that generates high-energy neutrons by a nuclear stripping reaction with flowing liquid lithium targets. The targets will be located in two identical irradiation test cells, either of which will provide an irradiation volume of $10 \mathrm{~cm}^{3}$ at a neutron flux of $10^{15} \mathrm{n} / \mathrm{cm}^{2}-5$ and $500 \mathrm{~cm}^{3}$ at a flux of $10^{14} \mathrm{n} / \mathrm{cm}^{2}-5$. FMIT has been authorized by the US Congress and will be constructed and operated by the Hanford Engineering Development Laboratory (HEDL) at Richland, Washington, in collaboration with the Los Alamos Scientific Laboratory (LASL) which is providing the accelerator design. The project is currently entering the detailed design phase, targeting for start of construction in early 1980 and operation in 1983-84. Research and development programs are underway at both HEDL and LASL to resolve uncertainties in the lithium target and accelerator designs.

\section{INTRODUCTION}

The Fusion Materials Irradiation Test Facility (FMIT), to be built on the federally-owned Hanford Site near Richland, Washington, is one of the first major steps in the fusion materials program wich will lead to comercial fusion power plants early in the next century.

FMIT will provide the on ly high-fluence data from a fusion-like radiation environment with in the next decade. Before these data are available, important decisions on alloy selection and on the comparative importance of various material properties will occur. of necessity, the major bas is for these decisions will be data from fission reactors. FMIT's mission will be to provide "keystone" data for applying the available data base to the damage regime for a fusion environment. Specifically, this correlation will involve verifying and updating earlier decisions, based on data from fission reactors and other radiation sources, and calibrating the andytical mode ls for applying these data.

A well recognized example of the difference in damage produced in fission reactors compared with a high-energy neutron spectrum is gas production. High-energy fusion neutrons are also prolific producers of helium and hydrogen gas through the nuclear transmutation reactions that they induce in the surrounding material. The helium and hydrogen contents in the structural materials will be 20-180 times as large as lliuse produced in fisston reactors. Little is known about the degradation in material properties resulting from the combination of

*Sponsored by U.S. Department of Energy Contract EY-76-14-2170 high gas production and high displacement damage. Another example of anticipated experimental interest for FMIT is the genera 1 question of long-term phase stability during exposure to high-energy neutron irradiation. Tests to address these and other materials questions will require irradiation to goal fluences approaching the lifetime of a fusion first wall. Accelerated testing in FMIT will be vital for timely development of these data.

\section{SOURCE DESCRIPTION}

The FMIT facility produces neutrons by stopping a $100 \mathrm{~mA}$ beam of $35 \mathrm{MeV}$ deuterons in a flowing lithium target $2 \mathrm{~cm}$ thick. The dominant nuclear reaction is a stripping reaction which results in a strongly forward-peaked neutron field, with gradients along the beam direction being less severe than the $\left(1 / R^{2}\right)$ dependence of a point source.

FMIT will produce about $3 \times 10^{16}$ neutrons per second with a fair ly broad energy peak. Along the beam direction and beyond several centimeters from the target, the spectrum exhibits a broad peak at about $15 \mathrm{MeV}$ and extends to over $30 \mathrm{MeV}$. For points off axis or close to the target, the peak evolves into a broad shoulder.

FMIT will provide an irradiation volume of $10 \mathrm{~cm}^{3}$ at fluxes above $1015 \mathrm{n} / \mathrm{cm}^{2}-\mathrm{s}$ and $500 \mathrm{~cm}^{3}$ at fluxes above $1014 \mathrm{n} / \mathrm{cm}^{2}-\mathrm{s}$. These high fluxes will permit testing at accelerated dis placement damage rates. With in a test volume of $140 \mathrm{~cm}^{3}$, the displacement rate in stee 1 exceeds that in a conceptual D-T fusion reactor 
first wall loading of $1 \mathrm{mw} / \mathrm{m}^{2}$. With in a volume of about $10 \mathrm{~cm}^{3}$, the displacement rate exceeds that of a first wa 11 loading of $4 \mathrm{~m} / \mathrm{m}^{2}$. The peak displacement rate corresponds to about $10 \mathrm{MW} / \mathrm{m}^{2}$.

- The ratio of helium production to displacement production is about the same as in a conceptual D-T fusion reactor first wa 11 spectrum. Because of its broadly peaked spectrum FMIT will produce some neutrons at energies significantly higher than a fusion first wall spectrum. Thus, there is an increasing need for nuclear data and radiation damage analys is at the se high energies. FMIT will also have the capability to operate at an intermediate beam energy in the range of $20-25 \mathrm{MeV}$, which can be utilized as an intermediate spectrum to study any high sensitivity to neutron energy that may be discovered. More detailed information in FMIT's source spectrum and the flux distribution may be found elsewhere in these proceedings 1,2 .

\section{FACILITY DESCRIPTION}

The FMIT consists basically of an acceleratorbased neutron source and an experiment complex with two irradiation cells where experiments will take place. Figure 1 shows the functional components.

The FMIT facility design provides an underground vault to house the linear accelerator and the beam line which directs and focuses the beam to either of the two test cells. The lithium supply system and test ce 11 complex are housed in the Test Building. The test cell complex will consist of two identical irradiation cells, each providing a clear test volume five-feet-wide by six-feet-deep by six-feethigh, and an overhead service ce 11. Each test Ce 11 will have horizontal ports providing side access to position sma11, standardized modular test assemblies in the high-flux regions behind the lithium target. Vertical access will also be provided through large sliding plugs in the test cell roofs that open into the service cell. Shielded transfer casks will be provided to transport irradiated test assemblies to examination facilities elsewhere on the Hanford Site.

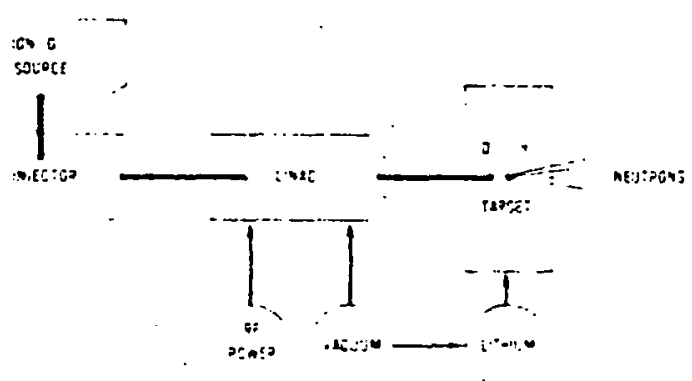

Fig. 1. Principle of FilT operation.

\section{EXPERIMENTAL SYSTEM}

The high energy and high flux of neutrons in FMIT require massive shielding around the irradiation cells. The design must provide adequate biological shielding and yet versatile access for experimenters. This has been accomplished with a dual access mode.

Figure 2 shows an elevation view of an irradiation cell and the provisions for side and overhead access. This general approach of independent access provides important advantages in simplifying. and improving the efficiency of handling operations.

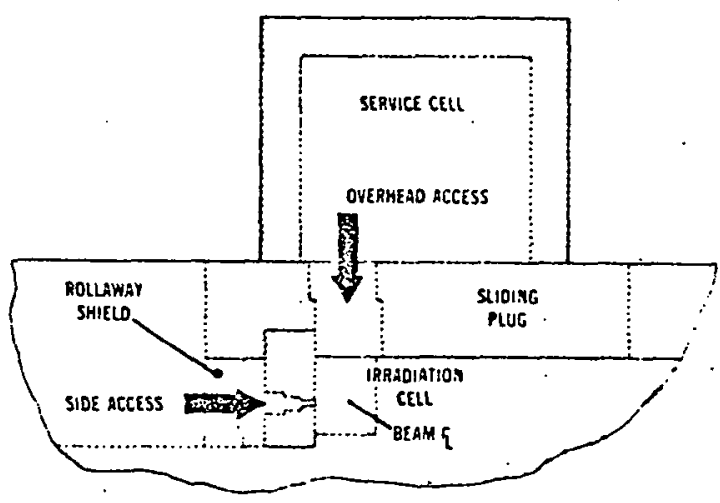

Fig. 2. FMIT test cell.

The irradiation cells will become highly radioactive and all activities conducted with in the irradiation cell, such as positioning experiments or maintaining in-cell equipment, will require remote handling. Workers stationed outside the service cell will use such aids as TV cameras, periscopes and electrically-controlled mechanical manipulators to perform the necessary operations through the overhead access afforded by the siding plugs.

Detachable lithium target assemblies will be inserted and removed through the overhead access. The overhead access will also be used to install and service special test assemblies that require bulky hardware in the ir designs. For example, a special test assembly could incorporate a cyclic loading test machine.

Most of the irradiation experiments will be of the modular type shown in Figure 3. Miniaturized test specimens, sensors and control elements will be encapsulated in standardized components of the test module. The module itself, containing the test specimens, will extend into the irradiation test cell in bayonet fashion from a shield plug fitted into the horizontal side access port, as shown in Figure 4. The module will attach securely to a positioning device which will provide final alignment with the beam axis and neutron flux 
field. The modular test assemblies will conta in leads for instrumentation and coolant that can be connected to auxiliary equipment located in a manned access area outside the irradiation cell. This arrangement permits the experimenter to connect leads and perform operational checks manually rather than remotely. Further, the modular experiments will be inserted and withdrawn through the walls of the irradiation cells directly into shielded casks positioned in the manned access area. Consequently, these transfer operations can be staged in parallel with activities underway in the service cell, thereby improving the operational efficiency of the facility.

\section{STATUS OF FMIT}

The realization of FMIT as a research facility has come rapidly as part of the strong comitment to a national program for fusion technology. However, the potential application of a deuterium-lithium source has been recognized for some time. Extensive work at Brookhaven National Laboratory on the concept of a linear accelerator-based $\mathrm{d}-\mathrm{Li}$ neutron source was a major foundation for HEDL's present efforts.

The conceptual design of FMIT was completed in 1978 and Title I design, which will define significant plant features and base line cost est imates, began January 2, 1979. Construction at the Hanford Site will begin in 1980 and will be completed in 1983-1984, with a targeted cost of $\$ 83$ million dollars.

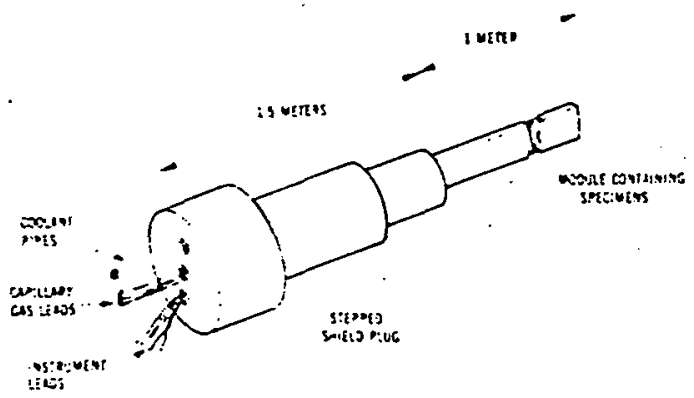

Fig. 3. Modular test assembly.

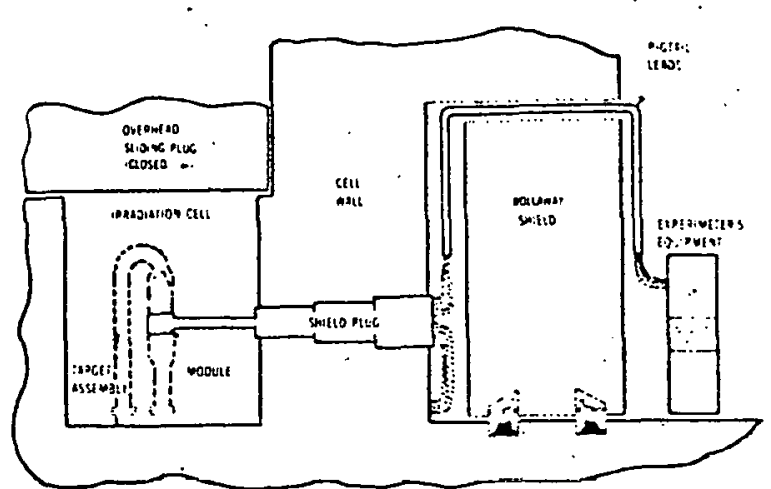

Fig. 4. Modular test assembly in place.

The two major development items required for FMIT are a linear accelerator that will deliver a $100 \mathrm{~mA}$ continuous-wave beam and a flowing lithium target capable of receiving the 3.5 megawatts of heat that the beam will deposit. The accelerator is a leap beyond existing accelerator technology. Los Alamos Scientific Laboratory will design FMIT's linear accelerator and is currently working on a prototype for testing. The lithium target and the circulating lithium systems are also advanced technology. Lithium will flow through a target at about 40 liters per second $(600 \mathrm{gpm})$. HEDL has already conducted preliminary water flow tests on a mock-up of the target. Ultimately, a prototypic lithium system and target will be constructed and qualified for use in FMIT.

FMIT will be a vital tool in fusion materials development. The authorization of this project and the strong support from the fusion comunity suggest a good future for FMIT and the fusion materials program.

References:

1. J. 0. Shiffgens, R. L. Simons, F. M. Mann and L. L. Carter, Journal of NuC. Mat., (this issue).

2. D. L. Johnson, F. M. Mann, J. N. Watson and $J$. UT Iman, Journal of Nuc. Mat., (th is issue). 